\title{
The job satisfaction of black female academics
}

\section{S. Schulze}

\author{
School of Education, \\ University of South Africa, \\ e-mail:schuls@unisa.ac.za
}

\begin{abstract}
The aim of this research was to investigate the job satisfaction of black, female academics at a distance education institution. To this end, a phenomenological method was employed. By means of purposeful and snowball sampling, ten participants from different departments in the humanities were recruited and interviewed. Participants were asked how they felt about teaching, research, community service, administration, compensation and job security, promotions, management, co-workers' behaviour and their physical environment. Findings indicate that the participants have a strong teaching orientation and need a supportive environment. Herzberg's theory on job satisfaction could only be partially confirmed. Management need to consider factors that influence satisfaction and dissatisfaction to improve the wellbeing of this group of academics.
\end{abstract}

\section{INTRODUCTION}

Locke (in Oshagbemi 1999, 388) described job satisfaction as 'a pleasurable or positive emotional state, resulting from the appraisal of one's job experiences'. According to Oshagbemi $(1996,389)$ job satisfaction is an important subject because of its effect on the physical and mental wellbeing of employees. It may affect absenteeism, turnover and motivation.

One of the best known theories on job satisfaction is that of Herzberg (1957) who argued that the opposite of job satisfaction is not job dissatisfaction, but no satisfaction. Similarly, the opposite of job dissatisfaction is not job satisfaction, but no job dissatisfaction. Intrinsic factors (e.g. achievement and responsibility), lead to job satisfaction when present, but do not produce dissatisfaction when absent. Extrinsic or 'hygiene' factors, (e.g. company policies, supervision and salary) cause dissatisfaction when inadequate but do not cause satisfaction, even when they are present.

The job satisfaction of black females in Higher Education in South Africa is not a well-researched topic. When job satisfaction and higher education were used as key words, the Index to South African Periodicals (ISAP) recorded 8 matches only for publications between 1987 and 2004. One South African study investigated job satisfaction among registered nurse tutors (Brink 1987) while another study focused on the job satisfaction of black, women academics at the University of Transkei (Linda 1995). In view of the fact that employment equity in South Arica 
encourages the employment and promotion of women as well as black employees to address gender and race inequities, it is likely that this particular group in the higher education sector will increase. The following words of Olsen, Maple and Stage $(1995,267)$ may be relevant to the South African context: 'By and large . . . enthusiasm for increasing the number of women and minorities [blacks] on our campuses has outstripped our understanding of the experience of these traditionally under represented groups in academe'.

Black, female academics may have to cope with significant challenges. For example, one study determined that they had to confront racism, sexism and special challenges in promotion and tenure (Singh, Robinson and Williams-Green 1995, 401). Niemann and Dovidio (1998, 56) also pointed out that black academics may operate in a state of reflective expectancy, believing that others hold stereotypical expectancies of them. Thus, the aim of this study is to investigate how South African, black, female academics experience their work.

\section{JOB SATISFACTION OF FEMALE ACADEMICS}

Kelly (1989, 446-452) determined that female academics were less likely than males to describe themselves as 'very satisfied'. Instead, there was a tendency to moderate their satisfaction level to 'fairly satisfied'. Accordingly, Hemmasi, Graf and Lust (1992, 439-441) found that males were marginally more satisfied with their work than females. Males tended to have higher satisfaction with pay than females, while females tended to have higher satisfaction with co-workers than males (Tang and Talpade 1999, 345).

Olsen et al. $(1995,284)$ reported that, if female academics felt less efficacious than males, they relied more heavily on external validation and were sensitive to a supportive environment. However, the females in their own sample reported a high level of intrinsic reward from their academic work. Self-efficacy (a sense of personal control over one's career) and the intrinsic reward of work are two important dimensions of job satisfaction (Olsen et al. 1995, 272-273). Olsen et al. $(1995,287)$ concluded that institutional support and work context were significant for job satisfaction.

Steward, Patterson, Morales, Bartell, Dinas and Powers (1995, 50-52) determined that the most significant interpersonal component contributing to the job satisfaction of female academics was a need for guidance. Female academics who indicated they did not need more guidance, experienced more job satisfaction. Women who wanted to fit in as valued members of their departments and who wanted assistance with doing so, tended to be the same women who were disappointed about what awaited them as academics (Steward et al. 1995, 52). Another study with female academics in the Indian Colleges of Dharwad and Hbli cities of Karnatak State, found that family responsibilities and attitudes towards teaching were the most influential factors in job satisfaction (Mukthamath, Gaonkar and Khadi 1991, 40). 
In a study with female academics in consumer sciences in different institutions in the United States of America (US), 75 per cent reported satisfaction with their jobs (Robertson and Bean 1998, 167). Socialisation, administrative climate, autonomy and financial rewards significantly influenced their satisfaction. Institutional type and discipline type also played a role (Ethington, Smart and Zeltmann 1989, 261).

In a Canadian study with women academics, interviews revealed that they did 'good' but felt 'bad' in the sense that they worked hard, supported colleagues and students and were good departmental citizens but felt bad about the results. This was related to a poor reward system, a feeling that they worked harder than the men and had to take responsibility for the nurturing and housekeeping side of academic life (Acker and Feuerverger 1996, 401). Earnshaw, Amundson and Borgen $(1990,14)$ also determined that females often worked harder than males because of being in temporary jobs.

\section{JOB SATISFACTION OF BLACK ACADEMICS}

Okolo and Eddy $(1994,345)$ investigated the level of job satisfaction of academics at historically black higher education institutions. They found that, in rank order, academics were satisfied with supervision, co-workers and work on their present job. Faculty members were satisfied with their job in general and with promotion, but dissatisfied with pay. Variables that correlated significantly with job satisfaction were salary, rank, age and level of education. Academics at institutions with better resources were significantly more satisfied than those with lesser resources, and those who were married were significantly more satisfied than those who were single.

More often than white academics, black academics taught undergraduate students, while white academics taught postgraduates (Allen, Epps, Guillory, Suh and Bonous-Hammarth 2000, 119). On average, black faculty members taught 1.5 hours per week more than their white counterparts and taught significantly more black students. Black academics were less inclined to judge black students as "academically unprepared" and reported more favourably on their ability to communicate with black students (Allen et al. 2000, 121).

Niemann and Dovidio (1998, 63-64) found that black academics reported higher levels of distinctiveness (the subjective experience of being viewed primarily in terms of category membership) and lower levels of job satisfaction than white academics. Investigators in the US have often described a kind of 'symbolic racism' toward black academe, which 'denounces overt forms of prejudice while denying access to resources, information and sources of support (many of which are informal) essential to success' (Olsen et al. 1995, 271). 


\section{JOB SATISFACTION OF BLACK FEMALES IN HIGHER EDUCATION}

An investigation of gender differences in the perceptions of black male and female academics determined that women indicated lower satisfaction than men with their professional lives, a greater sense of isolation on campus and worse treatment by colleagues of themselves and the suggestions they offered (Singh et al. 1995, 401 and 406; Olsen et al. 1995, 285-286). The women also reported fewer opportunities to work collaboratively with colleagues or be included in informal outings. Women also indicated a lack of administrative support and funding for research. Black females in the United States (US) HE system are concentrated at the lower levels of the academic system (Allen et al. 2000, 112). They are also the smallest group, outnumbered 2.5 to 1 by black males (pp. 117-126). White female and black male academics are three times more likely than their black female peers to express high general satisfaction with their work. Significantly more black, female academics than others are dissatisfied with their salaries. Black females are also the least critical of institutional leadership.

Research findings in the US generally indicate lower research productivity, a heavy teaching orientation and commitment to institutional service among black, female academics. They were less likely to receive institutional rewards based on scholarly productivity (Olsen et al. 1995, 268). In their own research, the women failed to demonstrate the bias toward service activities and less commitment to research although they spent less time on research (p. 1995, 283).

In a South African study at the University of Transkei, Linda $(1995,2)$ aimed to determine why black female academia occupied lower ranks of the occupational hierarchy and how this affected their job satisfaction. The study revealed a teaching orientation (p. 54). Thus, the women rejected publications as a criterion for promotion (p. 41). They wanted teaching, workload, student progress and community service considered. The study found a somewhat higher level of job satisfaction among male than among female academics. Both groups were satisfied with their jobs, supervision and colleagues but not with their salaries or opportunities for promotion (p. 49-50). The extent to which these findings were still valid, was determined by means of the following design.

\section{RESEARCH DESIGN}

\section{Research method and ethics}

The exploratory field research aimed at an in-depth understanding of the lived experience of female, black academics. Thus, a phenomenological method was appropriate.

The ethical measures undertaken included informed consent from all participants. They were assured of anonymity and confidentiality and their agreement to audiotape interviews was obtained (Strydom 2002, 62-75). 


\section{Trustworthiness}

Guba's model for trustworthiness addresses ways of reducing biases in the results (Poggenpoel 1998, 349-351). Within this model sampling decisions were carefully made. Care was taken to try and establish rapport before commencing with the interviews since the researcher is from a cultural group that is different (white, Afrikaans-speaking) from that of the participants. This is acknowledged as a limitation of the research. However, since participants were assured of confidentiality and anonymity, it was hoped that they answered truthfully. During the interviews, participants were probed when unsure about the meaning of their statements. All interviews were tape-recorded and transcribed verbatim. If additional information was needed, follow-up interviews were conducted. The investigation was conducted over a period of nine months until saturation point was reached.

\section{Sampling, data collection and analysis}

Purposeful and snowball sampling was employed. Ten participants, all involved in distance education and from the humanities, were interviewed. Maximum variation allowed for the inclusion of participants from Education, Sociology, Psychology, African Languages, English and Advanced Nursing. Their post levels varied from junior level to full professor and a departmental head. Their ages ranged from 30 to 54 and their years of experience in HE varied from three to 20 years.

Interviews commenced with some small talk before the actual interviews started (McNabb in Bender, Harbour, Thorp and Morris 2001, 782). Participants were asked how they felt about each of the following nine aspects of their work: teaching; research; community service; administration and own management; compensation and job security; promotions; management and leadership in their departments and in the university; co-workers' behaviour; and physical conditions and support. Finally, they were asked how they felt in general and whether they wanted to add anything. Interviews lasted approximately 60 minutes.Each of the nine aspects covered, formed a category. Within each of the categories, the data were divided into meaningful units and coded by sub-category names. Thereafter an attempt was made to establish how categories and sub-categories were related (Johnson and Christenson 2000, 426-431).

\section{FINDINGS}

\section{Teaching}

Satisfying aspects of teaching

As with the Olsen et al. (1995) study, the participants reported a high level of intrinsic reward from teaching and the fact that they could keep on learning and specialising. 
When I came [here] . . . I had to be an understudy to other people. Then I started reading more about it [and now] I love it more".

The challenge of designing "good" learning material was also enjoyed although mentors were sometimes required. Comments included:

I enjoy the teaching . . . I am learning a lot. The standard is high and I'm learning a lot. I feel that there is a certain growth that is happening in my life.

[Teaching] brought a challenge for me, because I had to start designing study material for students. Then I got to like it because it draws into your own inner resources. You've got to become much more creative. You've got to be very sensitive to the different types of students out there. That is the aspect I really enjoy.

What satisfies me is when I meet them and see, what I thought was easy, is actually a forest to them. They cannot make out head or tail. And when we go through it and I explain and we work on it together and try and merge . . you know, there is usually the very brilliant students and the not so brilliant students, so, to try and find the middle ground. When that synergy of minds happens, it satisfies me.

Fortunately when I worked in this department, I had a mentor. Wonderful. Administratively excellent. Very organised. She's this person I'm following up and who would want to see you a professor one day. So, for me that has been encouraging and satisfying.

Participants enjoyed their contribution to society. Since academics are perceived as experts, they are often invited to serve on boards 'which is actually exciting'.

\section{Frustrating aspects of teaching}

Aspects of teaching that caused frustration or dissatisfaction included heavy workloads, aggravated by semesterisation. This involved being responsible for a wide range of modules or a large number of students. The distance education context also required a great deal of written communication with students and administrative problems. Statements included:

I feel a bit overwhelmed at the moment. I think there is just too much work comparatively speaking. We as academics have to focus our attention on a diverse range of modules so that makes it difficult for us to feel competent.

Semesterisation more than doubled my workload. It's actually more about paper pushing than it is about quality delivery. With the year-long system, I could invite students to rewrite an assignment. Now there's no time for that.

I understand that we use marking to assess our students, but when we get a lot of 
examination papers and assignments to mark, it becomes a mechanical response. It is really not enjoyable and you're torn between standards and time pressures.

What dissatisfies me most is that there is a lot of administrative stuff that takes you away from the real teaching. For example, if students call and say they do not have the materials. At times the materials at the beginning of the year are there, but then they run out of stock. It's frustrating.

An added negative was the attitudes of some students. Soon after closing dates they would demand their marks or comment negatively on other lecturers.

\section{Research}

Participants were very aware of the need to publish. One senior participant stated that she adored research while another appreciated the fact that it forced her to update her knowledge. In contrast, one said:

I find sometimes there is too much pressure on lecturers to publish. I have concerns that the institution may find it is turning the lecturers into publication machinery. We don't have enough time to reflect on topics of research that are of good use to the community and of interest to the researcher.

Most participants had a greater orientation towards teaching than research, which is similar to what Olsen et al. $(1995,283)$ found in the US for black, female academics. In challenging the emphasis on research, one participant asked: 'What about those people who are good at teaching? What is the rest saying about them because we are teachers?'

The two most pressing problems concerning research, were lack of time and expertise. 'I find myself battling to be able to squeeze in time for research' was a typical remark. Regarding research skills, the need for training and/or a mentor, feelings of isolation and a need to work collaboratively with colleagues were communicated. This confirms previous findings for black females in the US (Steward et al. 1995, 50-52; Singh et al. 1995, 401, 406; Olsen et al. 1995, 258286). Statements include:

I still believe that we should undergo rigorous training . . . and also de-emphasise the older mode of individual research but encourage us and show us how we can do collaborative research ... In our faculty people are still working alone.

In our department is a lot of fragmentation because people have got a passion, a special field and click together . . . Around research, my passion is other things and I feel isolated.

I felt that I have inadequate skills, because when I was at University X, I wasn't supervising anybody. Here, at least, is a mentoring system. You would find that, as a 
person who doesn't have a D, if ever I have to supervise a student, there will be somebody who has a $\mathrm{D}$, and this person will be sort of mentoring me.

It was felt that such a mentoring system should be formal.

To have somebody appointed formally becomes much more easier because you know what, we've got a lot of work. So, it's not easy for me to come to you and say, would you please help me. It's not because you don't want to, but it's because you are also overworked. So, if we've got somebody formally appointed as a mentor . . . it gives you enough nerve to say, this is what I want to do.

When you enter a system, being new, you cannot tell who would be the right person to go to. So, if they get people appointed to serve as mentors, but make it flexible for you to change.

Participants sometimes found colleagues unsupportive and not interested in collaborative research and sharing credit. This confirms previous findings (Singh et al. 1995; Olsen et al. 1995). Another problem mentioned was that of being prevented from attending conferences because one did not have any previous research outputs. One participant said:

As a young researcher ... coming from a background where you didn't have enough exposure, it becomes very paralysing. There was funding only for those people who had money already. So you cannot even go there. How do you then start? How do you enter into the whole research arena? I had to fight it for myself . . . I had to contact the conference organising people and give them a bit of my dilemma and negotiate with them to do something for me.

On the positive side, the university's 'excellent library' and 'superb subject advisors' were mentioned. This confirms the importance of resources for job satisfaction (Okolo and Eddy 1994, 345). Another found the following system in her department very motivating:

If someone has published something . . . they will circulate it to all of us and congratulate the person. And when you read it, it's like your conscience speaks to you that I also have to do something.

\section{Community service}

Participant's responses on how they experienced community service, covered a wide range. One did not know exactly what it meant and some confessed to no involvement. Others saw it as 'interesting, but time-consuming' or as their duty. Another observed: 
I derive satisfaction, but sometimes I feel as an African woman with a doctorate in a European language, sometimes I feel . . . very . . . abused? . . . Because I have to be all over. My other field of specialisation is African languages ... Zulu and Swazi, I have postgraduate degrees in those. So I find myself having to work in language boards right across the country. It is beautiful . . but time . . it takes me away from home, the office, from teaching English. And then I don't know about the measure of accreditation.

Others emphasised how community service contributed to their job satisfaction, as was also found in the Olsen et al. (1995) study. For example, a psychology lecturer enjoyed applying the therapy that she learnt about. Another exclaimed:

I love it. I love it . . . I love to go out to the communities. It is my passion to contribute to the changing of peoples' lives. I like checking on people, what their problems are ... I love young people, I love women. I enjoy going out to schools. I go there on a reactive basis ... very little on a proactive basis ... I'm invited as a motivational speaker and sometimes I'm invited for career development. That's where I always pick up lots of emotional problems and I deal with them as they come. I walk with children and do emotional healing.

\section{Administration and own management}

Some participants were 'overwhelmed' and 'not in control' of their administrative duties as distance education lecturers. Two participants expressed the need for training:

I'm not, I'm not, I'm not [in control]. Actually . . . I have decided to register for a certificate in management. I'm hoping that I will be able to manage myself and also the teams that are put under me more effectively ... I'm too nice. Everybody comes 'Can you do this?' 'Yes!'. I do want to do it but it's self-destructive. And it subtracts from one's quality of work.In contrast, a senior lecturer observed:

I have my own diary of saying when to do X, Y, Z. And at the end of the day I am able to take stock of what I have achieved and where I couldn't and then I put a question mark so that I can follow up on that. [I am in control] because of experience ... it moves with you as you grow.

One lecturer felt that a lot of the administration that confronts lecturers, should actually not be their responsibility. She asked:

What is the function of a secretary? I type everything that I want. Then it is just for the secretary to format. So I find that I do most of my work on my own. And here you find that you are a student affairs office. Everything pertaining to student enquiries you have to handle and if you don't handle them, it gives a bad name to the institution. 
Regarding meetings, some participants stated that they experienced the number of meetings as reasonable and generally informative. 'Most of the time we have fruitful meetings. Sometimes we differ a lot, we get angry, but we deal with it and become a normal family again'.

Being in management, one participant who was head of a department declared:

It is terrible . . . if I can just see that word 'meetings' off the registers, off the dictionaries, off everything. Most of my time is in meetings. And these are meetings, which are intense and need action, even as you are doing something, it's changing the following day. So, you see, there is that frustration that we are involved in these meetings. You do something, and then tomorrow it is not even looked at. That adds to my dissatisfaction.

Finally, for one lecturer, dissatisfaction stemmed from the fact that many meetings were cancelled or arranged at short notice. 'I think it is all related to the whole transformation in the institution. I think there are more [managerial] challenges that trickle down', she said.

\section{Compensation and job security}

As with the Allen et al. (2000) study, the participants were unhappy with their salaries and felt these were not related to their input - the did 'good' but felt 'bad' feelings that Acker and Feuer $(1996,4)$ determined. One said, 'To tell you the truth, if I could get a job that would give me just R5 000 more than this, I would take it. But with pain, because I love what I'm doing.' Another said:

We're not being paid what we deserve and that is frustrating. If you speak with your peers in other places and they are well paid, and they are looking forward to going to work ... I think, for us, the only thing that really brings you to work, is once you get to love the students, that is something that gives you reason to wake up in the morning ... the passion and the love.

You can't find a person like Prof X [departmental head] anywhere. So . . . yes, sometimes I want to leave, you can't work for welfare anymore, but there are many other aspects ... working conditions, the fact that if you want to go abroad, I think I can do it, I visit places, I present papers. So, I'm not happy with the salary, but there are other issues that give me satisfaction.

Some participants felt secure in their work. 'I think, as a black female, I feel much more secure than my white female, male counterpart.' However, those who have not yet obtained permanent positions felt less secure. This was also true of the departmental head. Statements include:

We have been incorporated. And being incorporated anywhere in the world means no 
job security. If there have to be job cuttings, it means you are supposed to be the first person to go. That is reality.

I feel very insecure because of the mergers. You know, these posts are until the end of May, and then from there we are in these posts until the end of June. But now, in the meeting, someone said it's going to be extended for another three months. It goes on and on like that.

One participant mentioned diminishing student numbers in her department and asked, 'What would happen in 10, 15 years' time because of the decline in student numbers?'

\section{Promotions}

In Linda's (1995) study, female, black academia rejected the use of research and publication as criteria. In this study, participants generally found the promotion system 'flawed'. Dissatisfaction was related to lack of opportunities and an inconsistent system without transparency.

I'm not happy because I don't think they use a consistent system of making promotions. One minute they would say, these are the requirements. The next minute they change them. I was personally involved in this. I was appointed from the first of this year, and the way it was done in the department . . . it was not transparent . . . If I didn't fight for it, I don't think I would have been appointed a senior lecturer.

Some participants referred to affirmative action. One said:

It doesn't help to say, OK, because you are black, now you can be the head of the department. If we are going to look at affirmative action, we have to say: Is the person qualified enough? Is the person exposed enough? I'd rather have a lot of exposure and have a position that I am competent to really do the work, because if you're there and you aren't able to deliver... it's a lot of problems.

\section{Management and leadership}

\section{Departmental management}

In contrast to Linda's (1995) study that determined satisfaction with supervision, there were some negative views on leadership in departments. Promotion issues in particular caused distrust. One newcomer also felt that her department head did not help her to get settled. Thus, she felt 'overwhelmed'. Others were very satisfied. One called her supervisor (a white male), her 'mentor'. Satisfaction with leadership was enhanced if heads were approachable. The following is an example: 
She's very firm, but very welcoming, very accommodating. Not to the point of accommodating principles but she's very, very approachable and up to date with the needs of everybody. You wouldn't want a leader who has clear favourites or who is afraid to face issues. She's very brave, you know. But also a very, very gentle human being.

If the environment is not pleasant, you know, we have our stresses, but she [the head] tries to make the environment less stressful. And that contributes to effective working because you feel good about going to work.

\section{University management}

Some participants felt that they did not know the leadership in the institution well enough to comment. Others were dissatisfied, especially if the management style was perceived as autocratic.

I don't think management cares about the job satisfaction of employees. I think, personally, they are authoritative, top-down, nepotistic ... They don't care about us . . . we should be focusing on academic issues. [The institution] is targeted as a political icon, and that is my biggest problem.

Another participant believed management did not accept responsibility. She told of how a friend had a concern but was 'pushed' from one person to another. 'It's like nobody wants to take responsibility. A thing that could be solved in a week or so, takes about a year'.

Other participants were more satisfied with top management. This was enhanced if the managers were perceived as approachable and democratic or if staff was not retrenched even though student numbers in some departments decreased.

\section{Co-workers' behaviour}

In accordance with a previous South African study (Linda 1995), participants were generally satisfied with their colleagues. The department head declared, 'The people's relationships are tolerant. I think everybody is very adult. When there is disagreement, it is handled professionally'. Descriptions of relationships included 'harmony', being a 'family', sharing birthdays and hardships, a formalised 'caring club' and acceptance of differences. However, there was little evidence of personal friendships that prevailed outside the work environment. This is similar to findings for black female academics in the US (Singh et al. 1995, 401, 406, Olsen et al. 1995, 285-286). One female experienced academics as 'very distant, very cold', compared to administrative staff. However, another participant belonged to a group of friends of 'mainly white people' in her department. Regarding black-white 
relationships in particular, one said, 'Most of the time, blacks and whites work together in the department, but there are times when . . . I guess, blacks and whites feel comfortable in their own zones'.

Probing the issue of racism revealed that most had stories to relate. One said, 'You can also hear that they [whites] have a problem with affirmative action. If we were to be promoted, if we were to be the head, that is why I will not agree to be the head.' She continued:

If people are racist, I don't care. I've worked with whites before and I've seen good things about them, I've seen negative things about them. I also can be racist as a black person. So I'm not going to entertain those [thoughts].

Another example indicates the perception that white academics are more inclined than black academics to judge black students negatively, a confirmation of a study by Allen et al. $(2000,121)$. The following example illustrates this:

We have practical work components and the students are complaining about the few black supervisors. It is mostly white supervisors. They think that the white supervisors are racist. Very few black students get A distinctions and all the white students are passing with distinctions.

Two participants mentioned the fact that when they started at the university, people would talk Afrikaans and they could not understand. One said, 'I felt that they were cutting me out of the conversation. But then later on I started realising that some of them just do it spontaneously because it's their mother tongue. But still, it does not justify it.'

Another told of how, at a workshop, a video featuring the June 16 Soweto riots was played and a white professor said they should forget the past and move on. 'For me that was offensive. Yes, I need to move on, it's true, but for me I cannot cut off from what happened in my past. It reminds me of where I'm from and it gives me a sense of where I am going to'.

Yet another recalled how she and her colleagues were required to set multiplechoice questions. 'And then you come together and discuss them, and you wouldn't know wether they are discounting them because they are really bad multiple-choice questions, or simply because of the colour of your skin'. Similarly, another related how her assignment marks were questioned and that there was a tendency to make her responsible for African literature even though her speciality was Victorian and Shakespearean literature. She also felt that her promotion was seen as tokenism, related to gender and colour.

One participant experienced that her colleagues did not greet her. She recounted:

I came to a white department where there were only about three or four blacks . . . 
The people who are here are very nice, but I looked at things maybe from our cultural perspective. You know, to us greeting a person is important. But I realised that with people here, just to pass you ... it doesn't mean the person is angry with you.

Another participant told of how white students, when they phoned, would request to speak to 'the professor', assuming this person would be white. 'If the US, after all these years of independence, still struggles with the issue of racism, South Africa can't discard that overnight', was the observation.

Most participants said that they had not experienced any sexism. However, one maintained, 'We really do have the perception that it is only males who can lead. If females lead, we always question the position.' Another declared that males generally feel threatened by empowerment of women and by black women in particular. 'I hope the attitudes of males will change over time. They are changing, compared with a few years ago', she said.

\section{Physical conditions and support facilities}

Most complaints about physical environment revolved around computers (slow, outdated, waiting up to two weeks to have them fixed), offices (too hot, too small, poorly located) and parking facilities (too far). The following quotes illustrate:

It's a nightmare on the seventh floor. I think that floor was just an afterthought. Many people have complained about it [the heat during summer] for years and years.

Technical support is really below what it's supposed to be. Sometimes, if they don't actually respond to the request to come and help, and at the same time there is a deadline for tutorial letter 101, how do they then expect you to do that on time ... My computer is slow; it's terrible. You would find that when you came in new, you were told you couldn't get a better computer because you were still new. New people now come in and they get better computers than you do. It really demotivates you.

My office makes me dissatisfied. It could be better in terms of bigger, better ventilation, better sun . . you know, the position. It's horrible.

If participants had relatively new computers, they were satisfied. Satisfaction with the physical environment was also related to the fact that participants did not need to share offices but had their own private spaces to work in.

\section{General}

None of the participants were unhappy with their work. On the question of, in general, how satisfied they were, responses ranged from 'a bit discouraged' because she was not promoted to 'I love my job. It is the highlight of my life'. Aspects that participants found most satisfying related to teaching, private working areas, teaching autonomy and flexible working hours. 
For some, dissatisfaction arose from being involved with courses that did not interest them, their teaching load and too little student contact. For others, dissatisfaction related to poor salaries or lack of job security, recognition for work well done and convenient parking spaces. Nonetheless, a participant said she would recommend a career in higher education to other black females because 'there is a dire need for black, female academics as role models in South Africa'.

To enhance their job satisfaction, some participants said they would try to improve their research outputs. Others desired more contact with students, the principal or colleagues in other departments or a visit abroad.

\section{CONCLUSION}

In this research, Herzberg's theory on job satisfaction could only be partially confirmed. The job satisfaction of this group of black, female academics was related to many intrinsic aspects of their work, such as the enjoyment of teaching, contact with students, the growth teaching generated in themselves and using their expertise to serve their communities. However, in contrast to Herzberg's theory, their job satisfaction was enhanced by numerous job context features such as having their own private offices and working flexible hours.

Regarding dissatisfaction, Herzberg's theory could also only be partially confirmed. For example, in contrast to his theory, dissatisfaction was caused by issues with intrinsic factors, namely lack of achievement in the research field, heavy workloads and lack of contact with students. Other causes of dissatisfaction were a shortage of funding to attend conferences, being burdened with unnecessary administrative work and meetings, poor salaries, lack of job security and a flawed promotion system. Expressed dissatisfaction related to aspects of management, racism and weaknesses in the physical environment.

In summary, the following main themes emerged. The women in the sample had a strong teaching orientation. They also had a strong need for a supportive environment. This includes support to become skilled teachers, researchers and administrators, being well paid and financially sponsored to attend conferences, and working in agreeable emotional and physical environments. By considering these factors, management could improve the wellbeing of this group of academics so that they may not only 'do good', but also 'feel good'.

\section{REFERENCES}

Acker, S. and G. Feuerverger 1996. Doing good and feeling bad: The work of women university teachers. Cambridge Journal of Education, 26 (3): 401-422.

Allen, W. R., E. G. Epps, E. A. Guillory, S. A. Suh, and M. Bonous-Hammarth 2000. The Black academic: Faculty status among African Americans in US Higher Education. Journal of Negro Education 69 (1 and 2): 112-127. 
Bender, D. E., C. Harbour, J. Thorp, and P. Morris 2001. Tell me what you mean by "Si": Perceptions of quality of prenatal care among immigrant Latina women. Qualitative Health Research 11 (6): 780-794.

Brink, H. I .L. 1987. Job satisfaction and dissatisfaction among registered nurse tutors. Curationis, 10 (1 and 2): 11-16.

Earnshaw, A. R., N. E. Amundson, and W. A. S. Borgen 1990. The experience of job insecurity of professional women. Journal of Employment Counseling 27 (1): 2-18.

Ethington, C. A., J. C. Smart, and M. L. Zeltmann 1989. Institutional and departmental satisfaction of women faculty. Research in Higher Education 30 (3): 261-271.

Hemmasi, M., L. A. Graf, and J. A. Lust, 1992. Correlates of pay and benefit satisfaction: The unique case of public university faculty. Public Personnel Management 21 (4): 429-443.

Herzberg, F. 1957. Job attitudes: Review of research and opinion. Pittsburgh: Psychological Service of Pittsburgh.

Johnson, B. and L. Christenson, 2000. Educational research: Qualitative and quantitative approaches. Boston: Allen \& Bacon.

Kelly, J. D. 1989. Gender, pay and job satisfaction of faculty in journalism. Journalism Quarterly 66 (2): 446-452.

Linda, N. Y. 1995. Job satisfaction of black women academics and administrators at the University of Transkei. Master's thesis. Johannesburg: University of the Witwatersrand.

Mukthamath, G. C., V. Gaonkar, and P. B. Khadi, 1991. Factors influencing job involvement and job satisfaction among women teachers. Indian Journal of Behaviour 15 (3): 40-48.

Niemann, Y. F. and J. F. Dovidio 1998. Relationship of solo status, academic rank, and perceived distinctiveness to job satisfaction of racial/ethnic minorities. Journal of Applied Psychology 83 (1): 55-71.

Okolo, R. R. and J. P. Eddy 1994. A job satisfaction study of faculty at historically black colleges and universities in Texas. College Student Journal 28 (3): 345-346.

Olsen, D., S. A. Maple, and F. K. Stage, 1995. Women and minority faculty job satisfaction. Journal of Higher Education 66 (3): 267-293.

Oshagbemi, T. O. 1996. Job satisfaction of UK academics. Educational Management and Administration 24 (4): 389-400.

— T. O. 1999. Overall job satisfaction: How good are single versus multiple item measures? Journal of Managerial Psychology 14 (5-6): 388-403.

Poggenpoel, M. 1998. Data analysis in qualitative research. In Research at grass roots: A primer for the caring professions, ed A. S/ de Vos, 334-356. Pretoria: Van Schaik.

Robertson, L. J. and J. P. Bean, 1998. Women faculty in family and consumer sciences: Influences on job satisfaction. Family and Consumer Sciences Journal 27 (2): 167-193.

Singh, K., A. Robinson, and J. Williams-Green 1995. Differences in perceptions of African American women and men faculty and administrators. The Journal of Negro Education 64 (4): 401-408.

Steward, R. J., B. T. Patterson, P. Morales, P. Bartell, P. Dinas, and R. Powers, 1995. Women in Higher Education and job satisfaction: Does interpersonal style matter? NASPA Journal 35 (1): $45-53$.

Strydom, H. 2002. Ethical aspects of research in the social sciences and human service professions. In Research at grass roots: A primer for the caring professions, ed A. S De Vos, 62-75. Pretoria: Van Schaik.

Tang, T. L. and M. Talpade, 1999. Sex differences in satisfaction with pay and co-workers: Faculty and staff at a public institution of higher education. Public Personnel Management, 28 (3): 345-349. 